\title{
Potential of termite mounds and its surrounding soils as soil amendments in smallholder farms in central Uganda
}

\author{
Samuel Obeng Apori ${ }^{1,2^{*}} \mathbb{D}$, Marius Murongo ${ }^{1,4}$, Emmanuel Hanyabui $^{2}$, Kofi $^{\text {Atiah }}{ }^{2}$ and John Byalebeka ${ }^{3}$
}

\begin{abstract}
Objectives: The low fertility of highly weathered soils has been a major problem for resource-constrained smallholder farmers. In central Uganda, smallholder farmers have been collecting termite mound soils anywhere around the termite mound to improve their soil fertility. However, no studies have been conducted on which sections of the termite mounds consist of high soil nutrients. This study was conducted to assess selected major soil essential plant nutrients of soils collected from the top of the mound (TPMS), and the basal part of the mound (BPMS). The surrounding soil samples were collected from five, fifteen, and thirty meters away from the mound (TMSS1,TMSS2, and TMSS3 respectively), covering ten termite mounds in five different maize fields in central Uganda.

Results: TPMS and BPMS had significant (P-value<0.05) higher N, P, K, OC, Ca and Mg levels than TMSS1, TMSS2, and TMSS3. However, OC levels in BPMS was higher than TPMS. On the whole, termite mounds are beneficial as a source for essential plant nutrients. It will be best if smallholder farmers could collect the termite mound soils from the top and the basal part of the mound to improve the fertility of their soil.
\end{abstract}

Keywords: Nutrient index, Surrounding soil, Chemical properties

\section{Introduction}

In the tropical and subtropical Agroecosystem, the destructions and damages to crops and farm structures by termites have resulted in the reduction of crop productivity $[1,2]$. Out of the estimated total number of 2600 described species of termites, few have been considered as a major pest of food crops such as cereals, roots, tubers, legumes and fruit trees [3-6]. Despite being considered as pests, termites are biological indicators of soil fertility and ecosystem engineers [7-11]. Termite's activities such as collection and transportation of living and dead plants, animal materials, soil particles, and

\footnotetext{
*Correspondence: apori.samuel@umu.ac.ug

${ }^{1}$ African Center of Excellence in Agroecology and Livelihood System, Faculty of Agriculture, Uganda Martyrs University, Nkozi, Uganda Full list of author information is available at the end of the article Marius Murongo: Research and Knowledge pillar implementing partner for Uganda Martyrs University.
}

burrowing lead to the improvement of soil physicochemical properties and microbial population and diversity of the termite mound and their surrounding soils [12-17]. In central Uganda, most large termites mounds are built by Macrotermes subhyalinus and Macrotermes bellicosus and termite mounds found on farmlands are estimated to be on average 10-15 mounds per acre of land of a density between 0.1 and 3.4 per acre [18].

Soils found in central Uganda, are highly weathered Acrisol and Ferrasols [19] and are typically characterized by strong acidity, low cation exchange capacity, low nutrient retention capacity, and low available phosphorus $[20,21]$. The low fertility of the weathered soils has been a major problem for smallholder farmers who have limited financial resources to purchase commercially available fertilizers. To solve the problems created by these soils, poor smallholder farmers have been collecting soils from the termite mounds to amend their poor soils either 
solely or in combination with organic resources and fertilizers [22].

To date, there has not been any systematic study done in this sector of Uganda to ascertain which sections of the termite mounds consist of higher levels of macroelements to better inform smallholder farmers on which part should be harvested. The current practice amongst these farmers has been the collection of the surrounding soil from these termite mounds due to ease of collection compared to collection from other sections of the termite mounds. Due to the unavailability of or paucity of information regarding these practices amongst resourcepoor farmers in central Uganda necessitated this study. Therefore, the objective of this study was to assess the soil macronutrients, reactivity $(\mathrm{pH})$ and organic carbon contents of the different sections of the termite mounds and their surrounding soils. The main hypothesis being tested is that termite mounds and their surrounding soils differ in the nutrients and soil quality parameters being assessed. The results obtained from this study will improve the knowledge and practice of current integrated soil fertility management (ISFM) of resource-poor smallholder farmers in central Uganda.

\section{Main texts}

\section{Methods: study area}

The study was conducted in a maize field in Nkozi subcounty. Nkozi was chosen due to its widespread high termite mounds density. This study area lies at the equator with coordinates $0.0023^{\circ} \mathrm{N}, 32.0139^{\circ} \mathrm{E}$. The area receives a bimodal rainfall pattern with a mean annual rainfall of $1100 \mathrm{~mm}$ with minimum annual temperature ranges from 12 to $23^{\circ} \mathrm{C}$ and the maximum from 23 to $36^{\circ} \mathrm{C}$, respectively.

\section{Soil sampling}

Random soil sampling was done on ten termite mounds above three meters height found in five different maize fields. Two termite mounds were sampled from each of the five maize fields. The termite mounds that were mainly occupied by Macrotermes subhyalinus and Macrotermes bellicosus species were sampled for the current study $[18,23]$. Ten termite mounds were used as a sampling points. Soil samples were taken at the depth of $30 \mathrm{~cm}$ on the top of the mound (TPMS), and the basal part of the mound (BPMS). The surrounding soil samples were collected from five, fifteen, and thirty meters away from the mound (TMSS1, TMSS2, and TMSS3, respectively) using a soil auger (Fig. 1). The distances selected for the soil sampling of the surrounding soils were chosen to determine the variation of soil nutrients as the distance of surrounding soil increases [24]. The ten termite mounds were selected on a uniform slope in the five maize fields of average size of 4.5 acres. Five composite soil samples were taken from each of the ten mounds and

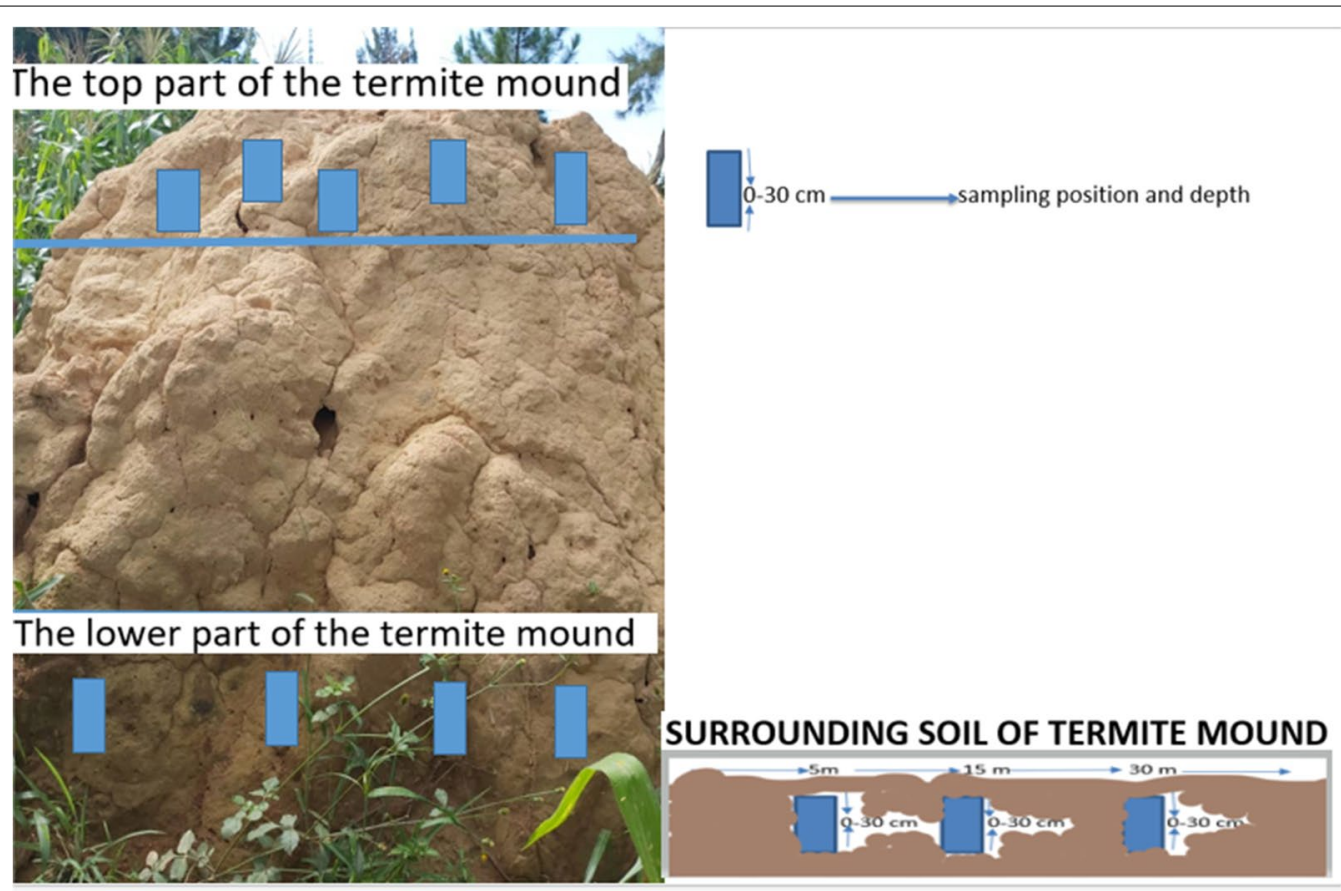

Fig. 1 Sampled sections of a termite mound (top and base), the surrounding soil at three distances and a sample depth of 0-30 cm. 
their surrounding soil. The soil samples were air-dried for two weeks after sampling from the field, sieved through a $2 \mathrm{~mm}$ mesh sieve and packed into sample bags and kept for soil analysis.

\section{Physicochemical analysis of the soil samples}

The soil $\mathrm{pH}$ was determined in soil: water suspension (1:5) [25]. The total organic carbon was determined by the colorimetric method [26]. Available P was analyzed using the bray 1 acid method [27]. Total nitrogen (N) was determined by the Kjeldahl method [28]. K was determined by a flame photometer [29] whiles $\mathrm{Ca}^{2+}$ and $\mathrm{Mg}^{2+}$ were determined by the atomic absorption spectrophotometer after extracting with $1.0 \mathrm{M}$ neutral ammonium acetate [29].

\section{Nutrient availability indexation}

To evaluate the nutrient status of the soil in the study area, $\mathrm{pH}$, organic carbon, available $\mathrm{P}$, exchangeable $\mathrm{K}$, calcium, magnesium and total nitrogen were calculated based on the specific rating chart (Additional file 1: Table S1) The nutrient index in soils were calculated using the method adopted by [30] (Additional file 1: Table S2): Nutrient index (N.I. $)=(\mathrm{L} \times 1+\mathrm{NM} \times 2+\mathrm{N}$ $\mathrm{H} \times 3) / \mathrm{TNS}$, Where $\mathrm{L}=$ Number of samples in the low category; $M=$ Number of the sample in the medium category; $\mathrm{H}=$ Number of the sample in High category, TNS $=$ Total number of samples. The nutrient index is used to predict the sufficiency of each soil quality indicators in fertile soil using soil test results obtained from the laboratory.

\section{Data analysis}

The data was analyzed using GenStat Edition 12 statistical software. One way ANOVA was used to compare some selected soil chemical properties of a termite mound and surrounding soil. Means were separated using Fisher's Unprotected Lsd at 0.05 significance level.

\section{Results}

Soil fertility assessment of selected properties of soil samples from termite mounds and their surrounding soil

Soil samples TPMS and BPMS had significantly (P-value $<0.05)$ higher contents of organic carbon, $\mathrm{N}, \mathrm{P}, \mathrm{K}$, and Ca levels compared to samples TMSS1, TMSS2, and TMSS3. There was no significant (P-value $>0.05$ ) difference in $\mathrm{pH}$ among the soil samples. The $\mathrm{pH}$ ranged from 5.72 to 6.18 . Organic carbon contents were significantly $(\mathrm{P}$-value $<0.05)$ higher in the top (TPMS) than any other section of the mounds plus its surrounding soils (Table 1). Organic carbon ranged from 1.59 to $0.47 \%$. However, no difference exists between TMSS2 and TMSS3. TMSS2 and TMSS3 which recorded OC of 0.57 and $0.47 \%$, respectively. The total $\mathrm{N}$ was significantly ( $\mathrm{P}$-value $<0.05)$ different from samples across the termite mounds sections. The values of total $\mathrm{N}$ across all samples ranged from 0.15 to $0.05 \%$ with the highest and the least being recorded by TPMS and TMSS3, respectively. There was significantly (P-value $<0.05$ ) higher contents of exchangeable $\mathrm{K}$ amongst samples of TPMS and BPMS compared to the surrounding soils. However, there was no significant (P-value $>0.05$ ) difference between TMSS2 and TMSS3. TMSS2 and TMSS3 recorded a potassium level of 0.18 and $0.15 \mathrm{cmol} \mathrm{kg}^{-1}$, respectively. The available phosphorus was higher in TMSS1 than TMSS2 and TMSS3. Available phosphorus for sample TMSS1 recorded $7.85 \mathrm{mg} \mathrm{kg}^{-1}$ while TMSS2 and TMSS3 recorded available phosphorus of 4.61 and $3.38 \mathrm{mg} \mathrm{kg}{ }^{-1}$, respectively. Exchangeable bases ( $\mathrm{Mg}, \mathrm{Ca}$ ) were significantly higher in TPMS and BPMS as compared to TMSS1, TMSS2 and TMSS3. However, calcium was higher in

Table 1 Selected chemical properties of soil samples of termite mounds and their surrounding soil

\begin{tabular}{|c|c|c|c|c|c|c|c|}
\hline Soil samples & $\mathrm{pH}\left(\mathrm{H}_{2} \mathrm{O}\right)$ & O.C (\%) & $N(\%)$ & $\mathrm{Mg}\left(\mathrm{cmol} \mathrm{kg}^{-1}\right)$ & $\mathrm{Ca}\left(\mathrm{cmol} \mathrm{kg}^{-1}\right)$ & $\mathrm{K}\left(\mathrm{cmol} \mathrm{kg}^{-1}\right)$ & Av. $P\left(\mathrm{mg} \mathrm{kg}^{-1}\right)$ \\
\hline TPMS & $5.72 a$ & $1.59 d$ & $0.15 c$ & $3.79 c$ & $9.13 e$ & $0.32 c$ & $16.47 d$ \\
\hline BPMS & $5.71 \mathrm{a}$ & $1.39 c$ & $0.15 c$ & $3.86 c$ & $8.40 d$ & $0.31 c$ & $15.64 d$ \\
\hline TMSS1 & 5.99ab & $0.80 b$ & $0.07 b$ & $3.24 b$ & $4.51 \mathrm{c}$ & $0.26 b$ & $7.85 c$ \\
\hline TMSS2 & $5.68 a$ & $0.57 a$ & $0.08 b$ & $3.43 b c$ & $4.03 b$ & $0.18 a$ & $4.61 b$ \\
\hline TMSS3 & $6.18 b$ & $0.47 a$ & $0.05 a$ & $2.27 a$ & $3.51 \mathrm{a}$ & $0.15 a$ & $3.38 \mathrm{a}$ \\
\hline P-value & NS & $* * *$ & $* * *$ & $* * *$ & $* * *$ & $* * *$ & ** \\
\hline SED & 0.18 & 0.05 & 0.01 & 0.23 & 0.21 & 0.02 & 0.55 \\
\hline
\end{tabular}

Means followed by the same letter in each column are not significantly different at $\mathrm{P} \leq 0.05$ using Fisher's unprotected LSD.

NS not significant

*significant at $\mathrm{P}<0.05$

** significant at $P<0.01$

**** significant at $\mathrm{P}<0.001$ 
TMSS1 and TMSS2 than TMSS3. TMSS1 recorded a calcium level of $4.51 \mathrm{cmol} \mathrm{kg}^{-1}$ while TMSS2 and TMSS3 recorded 4.03 and $3.51 \mathrm{cmol} \mathrm{kg}^{-1}$, respectively (Table 1).

\section{Nutrient availability index of termite mounds and surrounding soil}

Soil samples from TPMS, BPMS and TMSS1 recorded a high carbon content, TMSS2 recorded moderate and TSS3 recorded a low level of carbon content. Also, the nutrient index result indicated a high level of nitrogen content in soil samples TPMS and BPMS while TMSS1, TMSS2 and TMSS3 indicated low nitrogen contents. All the soil samples recorded a moderate level of magnesium content. TPMS, BPMS, TMSS1 recorded a high level of calcium content, TMSS2 for moderate and TMSS3 recorded low calcium content. Soil samples from TPMS and BPMS recorded a moderate level of Available phosphorus while TMSS1, TMSS2 and TMSS3 recorded low content. Potassium content was also high in TPMS and BPMS while TMSS1, TMSS2 and TMSS3 recorded a moderate level of potassium (Table 2).

\section{Discussion}

\section{Soil nutrients and soil quality indicators dynamics} of the termite mound

The $\mathrm{pH}$ of the soil from the termite mounds and its surroundings was weakly acidic. $\mathrm{Li}$ et al. [31], stated that most termite mounds are in acidic and weakly alkaline soils since higher soil $\mathrm{pH}$ leads to termite inactivation. Weak acidic soils play a significant role in increasing soil phosphorus availability [32], improve nutrient retention capacity [33] and creating favorable environmental conditions for soil microorganisms responsible for nitrogen and carbon cycling [34]. Most $\mathrm{pH}$ requirement for crops ranges from 5.5-5.8, therefore, collection of termite mound soils for amendments could meet most of the $\mathrm{pH}$ requirement for crops $[35,36]$. The higher organic carbon percentage in the termite mound was due to the organic materials used in its construction, and the types of food they eat. Termites feed on plant materials (live and dead plants, litter in various stages of decay), dung, soil and specialized food such as lichens [2, 37]. Some of the termites die and decay, thereby contributing to increasing soil organic carbon. The results obtained were similar to several other studies which concluded that organic carbon is higher in termites mound than the surrounding soil $[22,28,38,39]$. The OC recorded by the termite mounds and their surrounding soil falls above the SOC critical threshold at $0.4 \%$. However, collecting soil TPMS for application on the field will results in high crop productivity than the other sections of the mound [40].

The higher amount of N, P and $\mathrm{K}$ in termite mound compared to surrounding soils was due to the cumulative effect of organic matter by the termites in their mound. The accumulation of the organic matter in the termite mound increases plant macronutrients such as nitrogen, phosphorus and potassium. De BRUYN and Conacher [41], stated that the capacity of termites to increase nutrient levels such as nitrogen, phosphorus potassium, calcium and magnesium are dependent on the rate of organic material incorporation and the type of artificial mound made by the termites. In the work of Arshad [37], where termite mounds were combined with soil, the results showed high percentages of plant nutrients such as calcium, mineral nitrogen, extractable potassium

Table 2 Nutrient index of selected properties of 10 soil samples of termite mounds and its surrounding soil

\begin{tabular}{|c|c|c|c|c|c|c|}
\hline Soil sample locations & O.C (\%) & $\mathrm{N}(\%)$ & $\mathrm{Mg}\left(\mathrm{cmol} \mathrm{kg}^{-1}\right)$ & $\mathrm{Ca}\left(\mathrm{cmol} \mathrm{kg}^{-1}\right)$ & $\mathrm{K}\left(\mathrm{cmol} \mathrm{kg^{-1 } )}\right.$ & Av. $P\left(\mathrm{mg} \mathrm{kg}^{-1}\right)$ \\
\hline \multicolumn{7}{|l|}{ TPMS } \\
\hline Nutrient index & 3 & 3 & 2.1 & 3 & 3 & 2 \\
\hline Remarks & High & High & Medium & High & High & Medium \\
\hline \multicolumn{7}{|l|}{ BPMS } \\
\hline Nutrient index & 3 & 2.4 & 2 & 3 & 3 & 1.7 \\
\hline Remarks & High & High & Medium & High & High & Medium \\
\hline \multicolumn{7}{|l|}{ TMSS1 } \\
\hline Nutrient index & 2.8 & 1.6 & 2 & 2.6 & 2.3 & 1 \\
\hline Remarks & High & Low & Medium & High & Medium & Low \\
\hline \multicolumn{7}{|l|}{ TMSS2 } \\
\hline Nutrient index & 1.8 & 1.2 & 2 & 2 & 2.2 & 1 \\
\hline Remarks & Medium & Low & Medium & Medium & Medium & Low \\
\hline \multicolumn{7}{|l|}{ TMSS3 } \\
\hline Nutrient index & 1.6 & 1 & 1.9 & 2 & 2.1 & 1 \\
\hline Remarks & Low & Low & Medium & Medium & Medium & Low \\
\hline
\end{tabular}


and available phosphorus compared to the control. Jouquet et al. [42], stated that the grinding of soil particles by termite mandibles in the saliva-rich environment of the buccal cavity increases the surface area exposed to the surrounding, solution and then releases interlayer $\mathrm{K}$ and adsorption of hydrated or polar ions between the layers. Calcium content and magnesium were higher in the mound than the surrounding soil even though the nutrient index determination showed that there is a moderate level of calcium content for both the various section of the mound and their surrounding soils. The results are in agreement with Chisanga et al. [22] who reported a high concentration of $\mathrm{Ca}$ in soil from the top part of the termite mound.

\section{Conclusion and recommendation}

Both the top and the basal part of termite mound soils are beneficial as a source for major essential plant nutrients compared to the surrounding soil. However, extra research work on amending degraded soils with termite mounds' soils on plant nutrient availability should be done to elucidate their mechanism of improving soil fertility.

\section{Limitation}

In this study, some soil quality indicator parameters were not determined yet termite activities affect the biological and physical properties of the soil.

\section{Supplementary information}

Supplementary information accompanies this paper at https://doi. org/10.1186/s13104-020-05236-6.

Additional file 1: Table S1. Rating chart for soil parameters and their nutrient indices. Table S2. The nutrient Index with range and remark according to Ravikumar andSomashekar [30] was used in the study.

\section{Abbreviations}

TPMS: Soil samples from the top part of the termite mound; BPMS: Soil samples from the basal part of the termite mound; TMSS1: Five meters away from the termite mound; TMSS2: Fifteens meters away from the termite mound; TMSS3: Soil samples from thirty meters away from the termite mound; O.C: Organic carbon; Tot. N: Total nitrogen; Av. P: Available P; Ca: Calcium; K: Potassium; Mg: Magnesium.

\section{Acknowledgements}

The authors thank Ecological Organic Agriculture for their financial support and encouragement.

\section{Authors' contributions}

SOA and MM designed the research, collected the soil samples, and wrote the manuscript. EH and KA analyzed the data and revised the drafted manuscript. $J B$ contributed to the intellectual support in writing the manuscript. All authors read and approved the final manuscript.

\section{Funding}

Not applicable.
Availability of data and materials

All data generated or analyzed during this study are included in this manuscript.

\section{Ethics approval and consent to participate}

Not applicable.

\section{Consent for publication}

Not applicable.

\section{Competing interests}

The authors declare that they have no competing interests.

\section{Author details}

${ }^{1}$ African Center of Excellence in Agroecology and Livelihood System, Faculty of Agriculture, Uganda Martyrs University, Nkozi, Uganda. ${ }^{2}$ Department of Soil Science, University of Cape Coast, Cape Coast, Ghana. ${ }^{3}$ Faculty of Agriculture, Uganda Martyrs University, Nkozi, Uganda. ${ }^{4}$ Ecological organic agriculture initiative, Nairobi, Kenya.

Received: 22 May 2020 Accepted: 17 August 2020

Published online: 27 August 2020

\section{References}

1. M Lepage JP Darlington 2000 Population dynamics of termites T Abe DE Bignell M Higashi T Higashi Y Abe Eds Termites: evolution, sociality, symbioses, ecology Springer, Dordrech Berlin 333361

2. Apori SO, Flarian MM, Hanyabui E, Muli GK, Wamuyu B. Role of military termites (Pseudocanthotermes militaris) in improving soil productivity in tropical agroecosystems. Ann Res Rev Biol. 2020;18:14-9.

3. Wood TG, Smith RW, Johnson RA, Komolafe PO. Termite damage and crop loss studies in Nigeria-preharvest losses to yams due to termites and other soil pests. Trop Pest Manag. 1980;26:355-70. https://doi. org/10.1080/09670878009414916.

4. Loko YL, Agre P, Orobiyi A, Dossou-Aminon I, Roisin Y, Tamo M, Dansi A. Farmers' knowledge and perceptions of termites as pests of yam (Dioscorea spp.) in Central Benin. Int J Pest Manage. 2015;62:75-84. https ://doi.org/10.1080/09670874.2015.1107151.

5. Vasanthi EAP, Rajavel DS. Effect of sesamin on termites, Odontotermes wallonensis (wasmann) in groundnut. J Entomol Res. 2016;40:17-20. https ://doi.org/10.5958/0974-4576.2016.00003.7.

6. Tenon C, Akpesse AAM, Boga J-P, Yapi A, Kouassi KP, Roisin Y. Change in termite communities along a chronosequence of mango tree orchards in the north of Côte d'Ivoire. J Insect Conserv. 2016;20:1011-9. https://doi. org/10.1007/s10841-016-9935-1.

7. Martinez-Salgado MM, Gutiérrez-Romero V, Jannsens M, Ortega-Blu R. Biological soil quality indicators: a review, 2010.

8. Anderson T. Microbial eco-physiological indicators to asses soil quality. Agri Ecosyst Environ. 2003;98:285-93.

9. Deke LA, Adugna TW, Fite TA. Soil physic-chemical properties in termite mounds and adjacent control soil in Miyo and Yabello Districts of Borana Zone Southern Ethiopia. Am J Agric Forest. 2016;4(4):69-74.

10. Calovi DS, Bardunias P, Carey N, Scott Turner J, Nagpal R, Werfel J. Surface curvature guides early construction activity in mound-building termites. Philos Trans R Soc B. 2018;2019(374):03-74.

11. Enagbonma BJ, Babalola OO. Environmental sustainability: a review of termite mound soil material and its bacteria. Sustainability. 2019;11(14):3847.

12. Black HIJ, Okwakol MJN. Agricultural intensification, soil biodiversity and agroecosystem function in the tropics: the role of termites. Appl Soil Ecol. 1997;6:37-533.

13. Dangerfield JM, Mccarthy TS, Ellery WN. The mound-building termite Macrotermes michaelseni as an ecosystem engineer. J Trop Ecol. 1998:14:507-20.

14. Khucharoenphaisan K, Sripairoj N, Sinma K. Isolation and identification of actinomycetes from termite's gut against human pathogen. Asian J Anim Vet Adv. 2012;7:68-73.

15. Nithyatharani R, Kavitha US. Termite soil as bio-Indicator of soil fertility. Int J Res Appl Sci Eng Technol. 2018;6:659-61. 
16. Abe T, Bignell DE, Higashi M, editors. Termites: evolution, sociality, symbioses, ecology; 2000.

17. Mando A, Stroosnijder L, Brussaar L. Effects of termites on infiltration into crusted soil. Geoderma. 1996;74:107-13.

18. Pomeroy DE. Some effects of mound-building termites on soils in Uganda. J Soil Sci. 1976;27(3):377-94.

19. Jaetzold R, Schmidt H. Farm management handbook of Kenya-natural conditions and farm management information-vol II/A, West Kenya.

20. Jianping Z. Soil erosion in Guizhou province of China: a case study in Bijie prefecture. Soil Use Manag. 1999;15:68-70.

21. Mattina MI, Eitzer BD, lannucci-Berger W, Lee W, White JC. Plant uptake and translocation of highly weathered, soil-bound technical chlordane residues: data from field and rhizotron studies. Environ Toxicol Chem Int J. 2004:23:2756-62.

22. Chisanga K, Mbega ER, Ndakidemi PA. Prospects of using termite mound soil organic amendment for enhancing soil nutrition in Southern Africa. Plants. 2020;9(5):649.

23. Mali B, Okello S, Ocaido M, Nalule AS, Celsus S. Ethno charaterisation of termite species in the rangelands of central Uganda. Livest Res Rural Dev. 2018;30(1). http://www.Irrd.org//rrd30/1/b3ma30008.html.

24. Eneji IS, Sha'Ato R, Ejembi SE. Comparative analysis of termiteria and surrounding soil properties in the University of Agriculture, Makurdi, Nigeria. ChemSearch J. 2015;6(1):57-61.

25. Anderson JM, Ingram JSI. Tropical soil biology and fertility: a handbook of methods. 2nd ed. Aberstwyth: CAB International, The Cambrian News; 1993. p. 221.

26. Schulte EE, Hoskins B. Recommended soil organic matter tests. Recommended soil testing procedures for the Northeastern United States. Northeastern Regional Publication No. 493. 3rd ed, 2009; 8, p. 63-74

27. Bray RH, Kurtz LT. Determination of total, organic, and available forms of phosphorus in soils. Soil Sci. 1945;59(1):39-46.

28. Kaiser D, Lepage M, Konaté S, Linsenmair KE. Ecosystem services of termites (Blattoidea: Termitoidae) in the traditional soil restoration and cropping system Zaï in northern Burkina Faso (West Africa). Agr Ecosyst Environ. 2017:236:198-21111.

29. Rhoades JD. Cation exchange capacity. In: Page AL, Miller RH, Keeney DR, editors. Methods of soil analysis. Part 2. Chemical and microbiological properties. Madison, WI: American Society of Agronomy, Inc. Soil Science Society of America; 1982. p. 149-157.
30. Ravikumar P, Somashekar RK. Evaluation of nutrient index using organic carbon, available $P$ and available $K$ concentrations as a measure of soil fertility in Varahi River basin, India. Proceedings of the International Academy of Ecology and Environmental Sciences, 2013; 3(4):330-343.

31. Li Y, Dong ZY, Pan DZ, Pan CH, Chen LH. Effect of termite on soil pH and its application for termite control in Zhejiang province. China Sociobiology. 2017;64:317-26.

32. Audette $Y$. Effects of inorganic and organic amendments on soil phosphorus chemistry in calcareous soils (Doctoral dissertation).

33. Arshad MA, Coen GM. Characterization of soil quality: physical and chemical criteria. Am J Altern Agric. 1992;1:25-31.

34. Kemmitt SJ, Wright D, Goulding KW, Jones DL. pH regulation of carbon and nitrogen dynamics in two agricultural soils. Soil Biol Biochem. 2006;38(5):898-911.

35. McLean EO. Soil pH and lime requirement. Methods of soil analysis: Part 2 Chemical and microbiological properties. 1983;9:199-224.

36. Fageria NK, Zimmermann FJ. Influence of $\mathrm{pH}$ on growth and nutrient uptake by crop species in an Oxisol. Commun Soil Sci Plant Anal. 1998;29(17-18):2675-82.

37. Arshad MA. Influence of the termite Macrotermes michaelseni (Sjöst) on soil fertility and vegetation in a semi-arid savannah ecosystem. AgroEcosystems. 1982;8:47-58

38. Watson JP. The use of mounds of the termite Macrotermes falciger (Gerstäcker) as a soil amendment. J Soil Sci. 1977;28:664-72.

39. Lal R. Effects of macrofauna on soil properties in tropical ecosystems. Agr Ecosyst Environ. 1988;24:101-16.

40. Raina JN, Sharma JC, Sharma IP. Manual on methods for physical and chemical analysis of soils. Nauni: Department of Soil Science and Water Management, Dr Y.S Parmar University of Horticulture and Forestry; 2007.

41. De Bruyn L, Conacher AJ. The role of termites and ants in soil modification-a review. Soil Res. 1990;28(1):55-93.

42. Jouquet $\mathrm{P}$, Traoré $\mathrm{S}$, Choosai C, Hartmann C, Bignell D. Influence of termites on Macrotermes (Jsoptera, Termitidae) and the surrounding soils of the semiarid savanna of Malawi. J Agric Res. 2011;3:67-79.

\section{Publisher's Note}

Springer Nature remains neutral with regard to jurisdictional claims in published maps and institutional affiliations.
Ready to submit your research? Choose BMC and benefit from:

- fast, convenient online submission

- thorough peer review by experienced researchers in your field

- rapid publication on acceptance

- support for research data, including large and complex data types

- gold Open Access which fosters wider collaboration and increased citations

- maximum visibility for your research: over $100 \mathrm{M}$ website views per year

At BMC, research is always in progress.

Learn more biomedcentral.com/submissions 